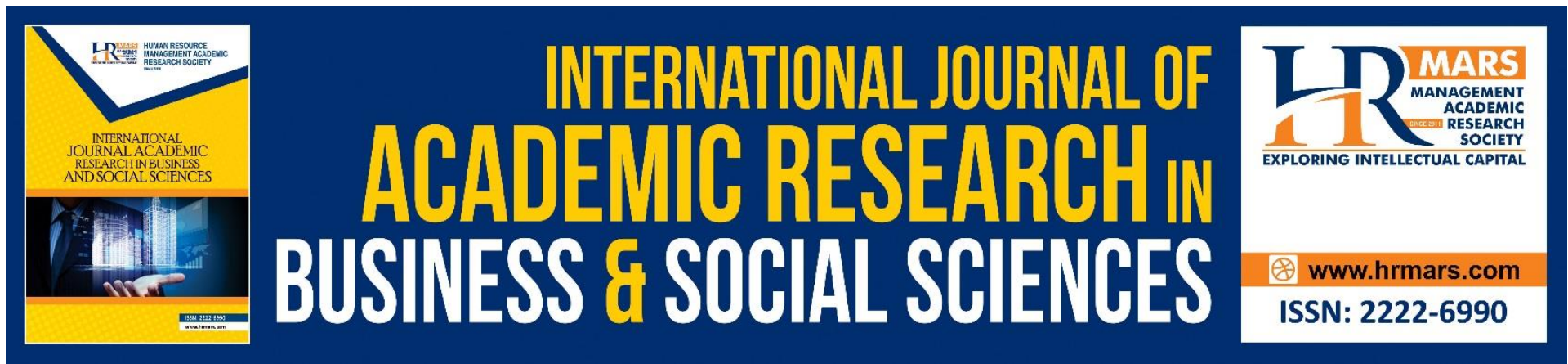

\title{
The Understanding of Sales Promotions' Influence on Food and Beverages Products in Malaysia
}

Nurul Zarirah Nizam, Yusri Arshad, Siti Hindun Supaat

To Link this Article: http://dx.doi.org/10.6007/IJARBSS/v8-i10/5313

DOI: $10.6007 /$ IJARBSS/v8-i10/5313

Received: 07 Oct 2018, Revised: 26 Oct 2018, Accepted: 09 Nov 2018

Published Online: 10 Nov 2018

In-Text Citation: (Nizam, Arshad, \& Supaat, 2018)

To Cite this Article: Nizam, N. Z., Arshad, Y., \& Supaat, S. H. (2018). The Understanding of Sales Promotions' Influence on Food and Beverages Products in Malaysia. International Journal of Academic Research in Business and Social Sciences, 8(10), 1566-1575.

Copyright: (c) 2018 The Author(s)

Published by Human Resource Management Academic Research Society (www.hrmars.com)

This article is published under the Creative Commons Attribution (CC BY 4.0) license. Anyone may reproduce, distribute, translate and create derivative works of this article (for both commercial and non-commercial purposes), subject to full attribution to the original publication and authors. The full terms of this license may be seen

at: http://creativecommons.org/licences/by/4.0/legalcode

Vol. 8, No. 10, 2018, Pg. 1566 - 1575

http://hrmars.com/index.php/pages/detail/IJARBSS

JOURNAL HOMEPAGE

Full Terms \& Conditions of access and use can be found at

http://hrmars.com/index.php/pages/detail/publication-ethics 


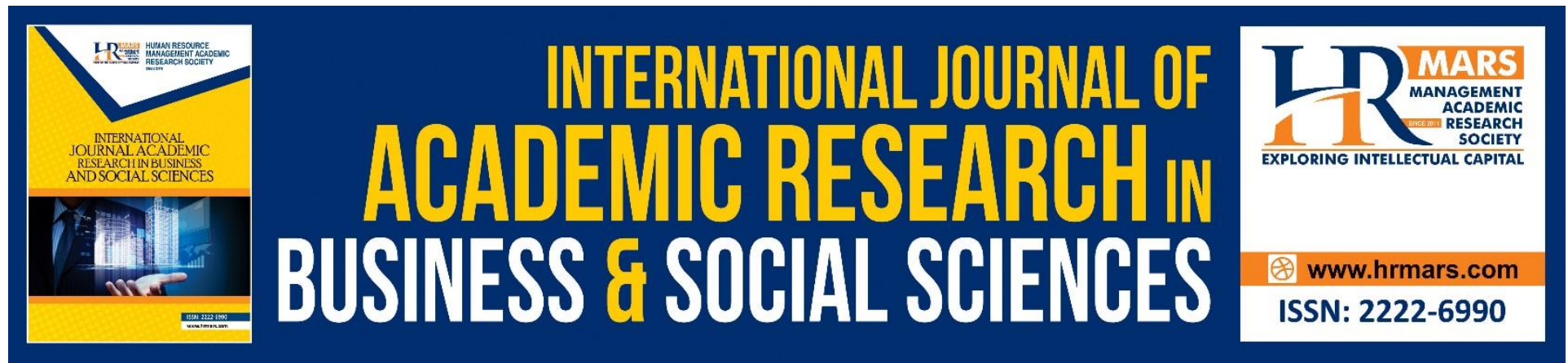

\title{
The Understanding of Sales Promotions' Influence on Food and Beverages Products in Malaysia
}

\author{
Nurul Zarirah Nizam and Yusri Arshad \\ Faculty of Technology Management \& Technopreneurship, Universiti Teknikal Malaysia \\ Melaka, Malaysia \\ Corresponding Email: zarirah@utem.edu.my
}

\author{
Siti Hindun Supaat \\ Centre of Graduate Studies, Universiti Teknikal Malaysia Melaka \\ Malaysia \\ Email: sitihindunsupaat@yahoo.com
}

\begin{abstract}
The purpose of this research is to identify the relationship between the types of sales promotion in food and beverage products and the influences of sales promotion on customer's decision making. The population of the research is made up of 150 respondents from Kuala Lumpur. The paper used convenience sampling for the selection of the respondents. Questionnaires were distributed to the respondents for statistical analysis through social media platform. The research utilized Statistical Package for the Social Sciences (SPSS) to analyze the data collected. The research revealed a number of findings including such as: Monetary promotions in food and beverage products have positive influences on customer's decision making; Non-monetary promotions in food and beverage products have positive influences on customer's decision making. Based on the findings, some conclusions were made most importantly to understand which sales promotion will bring more values and benefits.

Keywords: Sales Promotions, Decision Making Process, Monetary Promotions, Non-Monetary Promotions

\section{Introduction}

Plenty of research and study done on marketing strategies, there are only little academic oriented research on sales promotions related issues. Most of them are insensible of the factual essence of this sales promotions in food and beverage products towards customers. Keeping these drawbacks, this research is carried out to understanding the influences of sales promotions on customer's decision making with a study on food and beverage products. Despite, food and beverage industry can promote their products by sales promotions, some industry never realize the full benefits of it and encounter a lot of problems such as failure in maintaining effective and efficient strategy performed.
\end{abstract}


Therefore, one of the major concerns in marketing strategy is that what promotional strategies should be carry out in promoting food and beverage products. Analysing and considering the suitable promotional strategies that can be perform to fulfill customer needs in obtain the information of food and beverage products. Marketing departments has received much attention in both the popular press and academic literature in this recent years (Michael et al, 2014). Marketing department has a direct effect on profitability and sales so it is one of the important role in business. Marketing strategies also able to identify the customer needs and deliver useful information about food and beverage products. In the Malaysian retail environment, sales promotion activities are mainly used to attract customers to purchase. Nevertheless, not all sales promotion techniques can help marketers to sell their products. Some techniques are more preferred than the others, particularly in the Malaysian context (Teck et al, 2013).

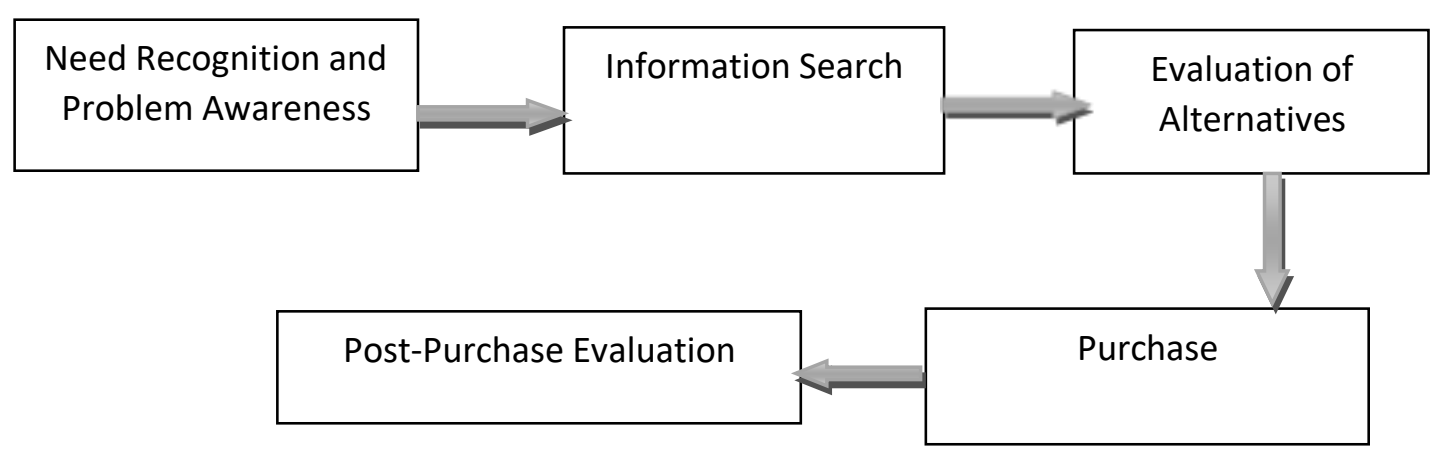

Figure 1. Decision Making Process by Customers

Source: Adapted from Familmaleki et al. (2015)

Marketing strategies include analyse of food and beverage product and it have been considered in depth in the literature (Dunn and Wickham, 2015). The food and beverage industry operated at different levels of society. Food and beverage is common and universal to human life and it also plays a unique role in expanding economic opportunity. Promotions can be considered as Integrated Marketing Communication (IMC) mainly consist of messages and related media that are used to communicate with the market. A company adopts strategies that coordinate different promotional elements. These promotional activities are integrated with other marketing activities that communicate with customers can be defined as IMC (Familmaleki et al., 2015). They also defined that customers must be go through the five stage process in decision making when purchase of any products. It is a process for customers to think what they want to buy, how much is the price and the quantity want to buy with respect to the factors affecting customer's attitude during this process as showed in figure 1 above.

Fazal et al. (2017) explained that sales promotion is a set of diverse and often short-term stimulant tools used to stimulate consumers or business unit to buy faster or buy more goods or services provided. It is clearly demonstrated there will be a long-run profitability with sales promotion (Tsiros and Hardesty, 2010). Once the products are researched and developed, 
promotion can be a key element in communicating the benefits of products. It is obvious that sales promotions can guide business into the

development of financial goals. Well-designed marketing and promotional strategies bring in more customers, ensure long-term success and profitability for businesses. Sales promotion activities are primarily used to attract new customers, lead existing customers to purchase more and encourage customer switching in the Malaysian retail environment (De Run et al., 2010). However, it is believed that the goal of sales promotion is to increase profit margin in instant sale by attracting existing and potential customers toward business activities.

\section{Problem Statement}

There are challenges faced by food and beverage products that will influence on customer's decision making and there are also limited study that focus on types of sales promotion in food and beverage products and influences of sales promotion on customer's decision making. Hence, this concern had formed the underlying problem of this study: whether the sales promotion can influence customer's decision making on food and beverage products and the effectiveness of sales promotions affect customer's decision making in purchasing food and beverage products. The past researchers the Wilson (2013) found that there are many challenges faced by food and beverage products in the development. There are many uncertain elements such as high price and lack of confidence towards product characteristics (Austin et al., 2017). When there is poor presentation of product information, it will result in distrust or unwillingness to buy.

Customers find it is difficult to understand the true information of food and beverage products which lead to the purchase decision (Tang et al., 2014). In other words, it is quite difficult to convince customers to purchase food and beverage products when they didn't receive any benefits or understand the products before making a decision. Kitchen et al. (2014) thus argued that it is necessary to develop and execute marketing strategies to provide information for customers, which then helps customers to make purchase decisions as an important issue for future food and beverage products studies.

The goal of this research was to determine the practice of the types of sales promotion in food and beverage products and influences of sales promotion on customer's decision making. In order to achieve the ultimate intention of this research, the objectives that were essential to be achieved are as follow; (i) to identify the types of sales promotion in food and beverage products that will influence customer's decision making, (ii) to determine the most effective types of sales promotion in food and beverage products that will influence customer's decision making, (iii) to identify the relationship between the types of sales promotion in food and beverage products and the influences of sales promotion on customer's decision making.

\section{Material and Method}

The study focused on the types of sales promotion in food and beverage products and how it influences on customer's decision making. The content scope comprised types of sales promotion in food and beverage products, as the independent variable and influences of sales promotion on customer's decision making as the dependent variable. The project based customers that were study in this research was limited to the 150 respondents. This research 
using online survey form to get respondent's feedback on sales promotion. Those respondents can answer the questionnaire through online because of the time essence and convenience. It covered for all purchase enabled customers in Kuala Lumpur to gain a deeper understanding the types of sales promotion in food and beverage products and influences of sales promotion on customer's decision making.

\section{Result and Discussion}

Table 1. Descriptive Analysis of Respondents Demographic Profile

\begin{tabular}{|c|c|c|c|}
\hline & & Frequency & Percentage \\
\hline \multirow[t]{2}{*}{ Gender } & \multirow{2}{*}{$\begin{array}{l}\text { Male } \\
\text { Female }\end{array}$} & 60 & 40 \\
\hline & & 90 & 60 \\
\hline \multirow[t]{4}{*}{ Age } & \multirow{4}{*}{$\begin{array}{l}20 \text { and below } \\
20-29 \\
30-39 \\
40-49 \\
50 \text { and above }\end{array}$} & 22 & 14.7 \\
\hline & & 53 & 35.3 \\
\hline & & 43 & 28.7 \\
\hline & & $\begin{array}{l}27 \\
5\end{array}$ & $\begin{array}{l}18.0 \\
3.3\end{array}$ \\
\hline \multirow[t]{3}{*}{ Race } & \multirow{3}{*}{$\begin{array}{l}\text { Malay } \\
\text { Chinese } \\
\text { Indian }\end{array}$} & 72 & 48.0 \\
\hline & & 52 & 34.7 \\
\hline & & 26 & 17.3 \\
\hline \multirow[t]{5}{*}{ Education Level } & \multirow{5}{*}{$\begin{array}{l}\text { SPM } \\
\text { STPM } \\
\text { Diploma } \\
\text { Degree } \\
\text { Master and above }\end{array}$} & 36 & 24.0 \\
\hline & & 14 & 9.3 \\
\hline & & 38 & 25.3 \\
\hline & & 54 & 36.0 \\
\hline & & 8 & 5.3 \\
\hline \multirow[t]{4}{*}{ Occupational } & Government Sector & 35 & 23.3 \\
\hline & Private Sector & 38 & 25.3 \\
\hline & Self-employment & 31 & 20.7 \\
\hline & Students & 46 & 30.7 \\
\hline
\end{tabular}

The background of the respondent is important in conducting research. This is because the respondent contributed to the value of the research as well. The general information of the respondents which involved the gender, age, employment status and spending hours on the internet (refer Table 1). The number of male respondents is more than female which represent 60 person (40\%) and 90 person (60\%) of each. Most of the respondents focused on the group of $20-29$ years old which were $35.3 \%$ or 53 respondents out of 150 respondents. Among them, $28.7 \%$ or 43 respondents is between 30-39 years old which rank the second highest participation in this research. The following were $18 \%$ or 27 respondents in the age group of 40-49 years old, follow by the age group below 20 years old which were $14.7 \%$ or 22 respondents. The last would be respondents that 50 years old and above about $3.3 \%$ or 5 respondents from 150 respondents. Most of the respondents were 20-29 years old because researcher focused on the youngster to conduct on this survey so 
that able to collect useful feedback from them to improve in influence customer's decision making in the future market. While for races, Malay was the most respondents participate in answered the questionnaire that included $48 \%$ or 72 respondents from the total respondents, Chinese occupied $34.7 \%$ or 52 respondents out of 150 respondents and Indian included $17.3 \%$ or 26 respondents. The highest proportion of education level among the respondents were Degree holder which included $36 \%$ or 54 respondents whereas the least proportion of education level was Master and above which is only $5.3 \%$ or 8 respondents. The rest were Diploma holder that included $25.3 \%$ or 38 respondents, SPM and below consisted of $24 \%$ or 36 respondents and $9.3 \%$ or 14 respondents were STPM. There were four categories of occupation in this research. Most of the respondents as a student that occupied $30.7 \%$ or 46 respondents. It was following by the private sector about $25.3 \%$ or 38 respondents out of 150 respondents. There are respondents work at government sector conducted this research which is $23.3 \%$ or 35 respondents. Self-employment had the least respondents that was only $20.7 \%$ or 31 respondents.

Table 2. Pearson's Product Moment Correlation Coefficient (PMCC)

\begin{tabular}{|l|l|l|l|l|}
\hline & 1 & 2 & 3 & 4 \\
\hline 1. Monetary Promotion (IV1) & 1 & & & \\
\hline 2. Non-monetary Promotion (IV2) & $.762^{* *}$ & 1 & & \\
\hline 3. Purchase Decision (DV) & $.783^{* *}$ & $.883^{* *}$ & 1 & \\
\hline
\end{tabular}

Note: $\mathrm{N}=150 * *$ Correlation is significant at the 0.01 level (2-tailed).

Table 2 stated that the $p$-value (sig.) of the correlation between independent variables (monetary promotion, non-monetary promotion and purchase decision) and the dependent variable (purchase decision) is less than 0.01 . This reflects that there is a significant relationship between them. The positive value of correlation coefficient indicated that the relationships between each independent variables and dependent variable are positively related. Pearson correlation for the first variables (IV1) was 0.783 with the significant level of 0.000 . This showed that there was a strong relationship between monetary promotion in food and beverage products and the influences of monetary promotion on customer's decision making. Next, the pearson correlation for the second variables (IV2) was 0.883 whereby the significant level was 0.000 . There was a strong relationship between non-monetary promotion in food and beverage products and the influences of non-monetary promotion on customer's decision making. In overall, the independent variables (monetary promotion, non-monetary promotion in food and beverage products) was correlated to the dependent variables (influences of sales promotion on customer's decision making). 
INTERNATIONAL JOURNAL OF ACADEMIC RESEARCH IN BUSINESS AND SOCIAL SCIENCES

Vol. 8, No. 10, Oct. 2018, E-ISSN: 222 2-6990 @ 2018 HRMARS

Multiple Regression Analysis

Table 3. R square

\begin{tabular}{|c|c|c|c|c|}
\hline Model & $\mathrm{R}$ & $\mathrm{R}$ Square & Adjusted R Square & Std. Error of the Estimate \\
\hline 1 & $.899^{\mathrm{a}}$ & .808 & .805 & .27522 \\
\hline
\end{tabular}

a. Predictors: (Constant), monetary promotion, non-monetary promotion

b. Dependent variables: purchase decision

Table 4. Coefficients

\begin{tabular}{|l|l|l|l|}
\hline & Beta & $\mathrm{t}$ & Sig. \\
\hline Monetary promotion & .263 & 4.702 & .000 \\
\hline Non-monetary promotion & .683 & 12.227 & .000 \\
\hline
\end{tabular}

a. Dependent Variable: Purchase Decision

From the table, it can notice that the two variables, which are the monetary promotion and nonmonetary promotion, have been tested with the dependent variable which is decision making. The $p$ value for the independent variable which is monetary promotion and non-monetary promotion both are 0.000 and 0.000 and all of these values are smaller than the 0.05 , this value showed that these two variables was significant when they are tested to the dependent variable. From the value above, we can concluded that our research was valid which the independent variable showed the significant effect on the dependent variable. The monetary promotion showed 0.263 and non-monetary promotion showed 0.683 . The beta of non-monetary promotion $(0.683)$ is higher than monetary promotion (0.263) indicated non-monetary promotion has bigger impact to the dependent variable. While the monetary promotion showed less impact with lower beta. That's mean factor of nonmonetary promotion have stronger effect in decision making.

\section{Conclusion}

Hypothesis 1: Monetary promotions in food and beverage products have positive influences on customer's decision making

Monetary promotion in food and beverage products has been proven have a significant relationship towards influences of sales promotion on customer's decision making.

The past researcher Teck Weng et al. (2013) discovered that monetary promotions in food and beverage products significantly influence customer's decision making. It was mentioned that Malaysian accepted monetary promotions because monetary based benefit important to Malaysia customers. They like the promotion techniques that offer them monetary value and would surely assist in their decision making. It can be concluded that customer's decision making can be affected by the appropriate sales promotion techniques in food and beverage products such as offer monetary benefits. Therefore, pervious study showed that monetary promotions had strong impact on customer's decision making when purchase food and beverage products. Hence, it also confirmed the 
INTERNATIONAL JOURNAL OF ACADEMIC RESEARCH IN BUSINESS AND SOCIAL SCIENCES

Vol. 8, No. 10, Oct. 2018, E-ISSN: 222 2-6990 @ 2018 HRMARS

importance of monetary promotions for repeat-purchase intentions. Monetary promotions activities able to attract customers and perceived them more positively in quality evaluations. Past research revealed that customers were more willing to return as a result of monetary promotions (Huang et al., 2014).

Hypothesis 2: Non-monetary promotions in food and beverage products have positive influences on customer's decision making

The finding on this research has shown that there was a significant positive relationship between the non-monetary promotion in food and beverage products and influences of sales promotion on customer's decision making.

According to Buil et al. (2013), free gifts as a promotional tool that can increase purchase intentions hence direct influence customer's decision making. It found that free gifts were equally suitable for both hedonic and utilitarian products. Free gifts can positively reinforce the purchase decision of customers in food and beverage products. Therefore, free gifts that offered able to be a wise alternative to increase the likelihood of choice of the promoted product. Free gifts must also be of interest to customers. Liang et al. (2017) identify that non-monetary promotions in food and beverage products had significant and positive relationship on customer's decision making. It was suggested that non-monetary promotions are considered as gains so customer's responses are more favourable for non-monetary promotions. Non-monetary promotions provide more benefits in terms of hedonic that make customers feel that they can gain more benefits. It will direct influence on their decision making. Non-monetary promotions can therefore evoke more associations related to decision making process, enjoyable experiences, feelings and emotions. Consumers tend to perceive non-monetary promotions separately from price information and encode them as gains (Tan and Bogomolova, 2016). In overall, non-monetary promotions provide benefits of sales promotions have greatly contributed to the understanding of customer's influences on decision making to sales promotion in the contributions of the personality studies, the parsimony of the economic perspective, and the existing work. (Chandon et al., 2000)

\section{Recommendation}

Future research suggested to conduct the research at different states to confirm the consistency of the findings by comparing the dataset with the present results. Therefore, a more precise result can be obtained from different states and generalized the result. Next, future research may include open ended questions in the questionnaire. Open-ended questions allow respondents to include more information, including feelings, attitudes and understanding of the subject. This allows researcher to better access the respondent's true feelings on an issue. Therefore, researcher can obtain more valuable and reliable findings from respondents. In questionnaire, the researcher can solve limited response problem by visit the respondents and explain to them the details of the survey. Therefore, the respondents more understanding the research and able to provide a more reliable answer. It may involved to visit each and every respondent personally. There are many types of marketing strategies which are interested to be studied on. Future researchers is recommended to have an in depth research that include other types of marketing strategy which is not included in this research. Hence, it also able to manage all the marketing activities that influence customer's decision making. 
Social media can become a fundamental part of the organization's overall marketing strategy and activities in order for it to yield full potential. It can be a powerful marketing strategy in food and beverage products to influence customer's decision making. Leung and Slegh (2015) revealed that a positive experience with Facebook which can influence the consumer's decision making would lead to a favourable attitude towards the Facebook page. Yi and Yoo (2011) also reported that advertising messages provided by Facebook enhances consumer's attitudes towards purchase intentions and had a greater impact than those sent by friends.

\section{Acknowledgements}

Thanks are expressed to Leong Pei Tjun for his help in collecting the data used in the study while fulfilling his role as an undergraduate student at the time.

\section{References}

Familmaleki, M., Alireza, A., \& Kambiz, H., 2015. Analyzing the Influence of Sales Promotion on Customer Purchasing Behavior. International Journal of Economics \& Management Sciences, 4 (4), pp. 2-6, http: 4 http://dx.doi.org/10.4172/2162-6359.1000243.

Michael, T. \& David, M. H., 2010. Ending a Price Promotion: Retracting It in One Step or Phasing It out Gradually, Journal of Marketing, 74 (1), pp. 49-64.

Tang, Y., Wang, Y. and Huang, J. (2014). Optimal promotional strategy for intra-category crossselling. British Food Journal, 116(1), pp.80-90.

Wilson, S. (2013). Categorizing WIP inventories in the food industry. Journal of Agribusiness in Developing and Emerging Economies, 3(1), pp.27-48.

Kitchen, P.J., Faridah Syed Alwi, S., Che-Ha, N. and Yee Lim, P. (2014). Coupon redemption behaviour: a Malaysian cross-segment investigation. Marketing Intelligence \& Planning, 32(1), pp.66-88.

Leung, A. and Slegh, D. (2015). Hedonic product discounts: When is the price right?. Nankai Business Review International, 5(4), pp.356-364.

Teck Weng, J. and Cyril de Run, E. (2013). Consumers' personal values and sales promotion preferences effect on behavioural intention and purchase satisfaction for consumer product. Asia Pacific Journal of Marketing and Logistics, 25(1), pp.70-101.

Huang, H., Chang, Y., Yeh, C. and Liao, C. (2014). Promote the price promotion. International Journal of Contemporary Hospitality Management, 26(7), pp.1065-1082.

Buil, I., de Chernatony, L. and Montaner, T. (2013). Factors influencing consumer evaluations of gift promotions. European Journal of Marketing, 47(3/4), pp.574-595.

Liang, A., Yang, W., Chen, D. and Chung, Y. (2017). The effect of sales promotions on consumers' organic food response. British Food Journal, 119(6), pp.1247-1262.

Tan, P. and Bogomolova, S. (2016). A descriptive analysis of consumer's price promotion literacy skills. International Journal of Retail \& Distribution Management, 44(12), pp.1223-1244.

Chandon, P., Wansink, B. and Laurent G. (2000). "A benefit congruency framework of sales promotion effectiveness", Journal of Marketing, Vol. 64 No. 4, pp. 65-81. 
INTERNATIONAL JOURNAL OF ACADEMIC RESEARCH IN BUSINESS AND SOCIAL SCIENCES

Vol. 8, No. 10, Oct. 2018, E-ISSN: 2222-6990 @ 2018 HRMARS

Yi, Y. and Yoo, J. (2011). The long-term effects of sales promotions on brand attitude across monetary and non-monetary promotions. Psychology and Marketing, 28(9), pp.879-896. 